\title{
REPORT
}

\subsection{3}

OF THE

\section{NATIONAL ZOOLOGICAL PARK COMIMISSION}

TO THE

SENATE AND HOUSE OF REPRESENTATIVES.

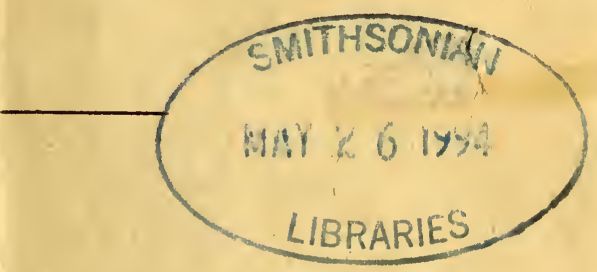

TRANSMITTED JANUARY 17, 1890.

WASHINGTON :

GOVERNMENT PRINTING OFFICE. 1890 . 


1st Session. $\}$ No. 72.

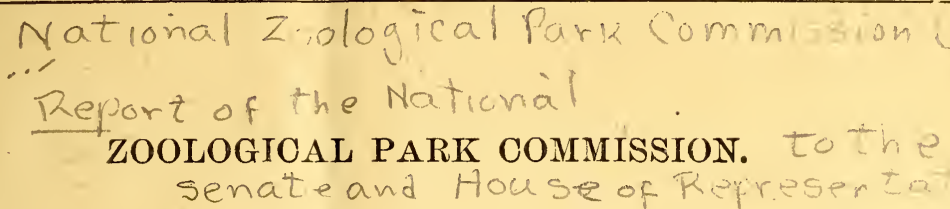

JANUARY 18, 1890.-Referred to the Committee on Appropriations and ordered to be printed.

\section{LETTER FROM THE SECRETARY OF THE SMITHSONIAN INSTITU- TION TRANSMITTING A REPORT OF THE ZOOLOGICAL PARK COMMISSION.}

\section{Smithsonian Institution, Washington, D. O., January 17, 1890.}

SIR: I am instructed by the Commission for the establishment of a zoological park in the District of Columbia to present a report. This report, signed in duplicate, I have the honor to iuclose to you.

Very respectfully, yours,

S. P. LANGLEy, Secretary Smithsonian Institution, And Secretary Zoological Park Commission.

The SPEAKER of THE House of REPRESENTATIVES.

REPORT OF THE PROCEEDINGS OF THE COMMISSION TO ESTABLISH A ZOOLOGICAL PARK IN THE DISTRICT OF' COLUNBIA.

Office of the Zoological Park Commission, Smithsonian Building, Washington, January 16, 1890.

To the Senate and House of Representatives in Congress assembled:

The Commission for the establishment of a zoological park has the honor to report that by the terms of the act of Congress entitled "An act making appropriations to provide for the expenses of the government of the District of Columbia for the fiscal year ending June 30, 1890, and for other purposes" (approved March 2, 1889), section 4 of which provides "for the establishment of a zoological park in the District of Columbia," this Commission was created and charged with the duty of selecting, within a specified area, a tract of land suitable for a zoological park, and of purchasing the same for the Government; and for this purpose an appropriation of $\$ 200,000$ was made.

The Commission was authorized and directed to make an inspection of the country along Rock Ureek, between Massachusetts avenue and the point where said creek is crossed by the military road leading west from Brightwood, and to select from that district of country a tract of land of not less than 100 acres, and which shall include a section of the creek, such as the Commission shall deem suitable and ap. propriate for a zoolugical park "for the advancement of science and the instruction and recreation of the people." 
On March 9, 1889, the Commission held its first meeting, effected an organization, and immediately thereafter began to inspect the country situated between the two points on Rock Creek that were designated by Congress. At the request of the Commission the Director of the Geological Survey caused to be prepared a preliminary map, based on the charts of the U. S. Coast and Geodetic Survey, showing the ownership of each separate parcel of real estate in the region available for the location of the park.

The members of the Commission made repeated personal tours of inspection to and through the various portions of the Rock Creek region between Massachusetts avenue extended and the military road, a tract of country over 3 miles in length, every portion of that region being visited and studied until the relative merits of the different possible sites for a zoological park were all considered.

Inasmuch as the act required that the first step toward condemnation proceedings should be the locating of the park, and the filing in the public records of a careful map of the same, "showing the location, quantity, and character of each parcel of private property to be taken," the Commission found itself confronted with the danger of locating a park which might afterward be condemned and appraised at a total valuation in excess of the amount appropriated. In view of this, of the numerous holders, and of the excessive prices in many cases demanded, it was decided to invite the various owners of lands aloug Rock Creek, between the two points indicated, to state to the Commission in writing the lowest prices at which they would be willing to sell all, or certain specified portions of their lands, for the purposes of a zoological park.

Accordingly, on April 15, a circular letter was prepared and sent to each of the various land owners, and a copy of the same is appended herewith, marked Exhibit A. The Commission also caused an advertisement to be inserted in various newspapers published in the eity of Washington, likewise calling upon the owners of land in the Rock Creek region, between the crossing of Massachusetts avenue extended and the military road, to state their lowest prices for the same. The replies received in answer to this circular letter and advertisement were generally unsatisfactory, in nearly every case the price asked being believed by the Commission to be in excess of the actual market value of the land, and in several instances being many times what seemed to it to be likely to be asked of a private purchaser.

Finding it impracticable to secure any co-operation from the property owners in its efforts to ascertain the value of land before locating the park, the Commission sought in various directions data for reliable in. formation as to these values; and, among other inquiries, asked the advice of prominent and disinterested citizens of Washington, whom it had reason to suppose possessed special ability in the determination of the value of real estate, these gentlemen giving much time and pains to enable them to answer the Commission's questions, without compensation or reward.

When the Commission felt that it had from these various sources acquired a preliminary knowledge of the prices which might reasonably be expected to result from the condemnation, it proceeded to locate tho park. After a full consideration of the relative merits of the different available sites, it was decided that the location proposed to Congress during the consideration of the Zoological Park bill was the best to be found, and indeed so well adapted to the purpose in view that, apart from the question of cost, it stood almost without a rival. 
Greatly to the satisfaction of the Commission, it was finally able to acquire a site in the region indicated to Congress by the maps and models submitted at the time of the final debate*, at a cost within the estimates submitted to Congress by the Secretary of the Smithsonian Institution, it being in fact able to purchase here at prices lower than were demanded in situations more remote from the city. In accordance with its best judgment, the Commission, finding itself thus able to secure more land than it had originally contemplated the possibility of doing, included in the area of the site about 167 acres, commencing at a point within less than 2 miles of the Executive Mansion.

On May 17, 1889, the general location and area was determined upon, and immediately thereafter the Director of the Geological Survey was requested to survey the same, and prepare a map in accordance with the requirements of the act for the establishment of the park.

Although many expressed the opinion that it would be found impossible for the Government to acquire any of the land by agreement at prices which would be given by a private purchaser, the Coinmission is able to report that of the entire 166.48 acres included in the park, it has finally succeeded in securing 131.14 acres by agreement with the several owners thereof, at prices satisfactory to all concerned. The Commission desires to place on record the fact that in its negotiations for the purchase of this land for the United States Government it was finally met by land-holders who owned nearly four-fifths of the park site in a spirit of fairness, and even liberality in some cases, which is certainly unusual in such transactions when the Government is the purchaser. The names of these holders will appear elsewhere in this report, in the schedule of property and property owners.

Of the remaining 35.34 acres in the park site, 34.49 acres will have to be acquired through condemnation proceedings, which are now in progress, and the balance of .84 of an acre is already the property of the Grorernment. The Commission has to acknowledge the tender to them as a gift of $\mathbf{5 . 1 0}$ acres of land from the Woodley Park Syndicate, represented by Mr. H. P. Waggaman, which was legally acquired for the nominal consideration of $\$ 1$.

On November 21 the survey of the park was completed, and a careful and accurate map thereof was furnished by the Director of the Geological Survey and filed by the Commission in the public records of the District of Columbia, as required by law; and your Commission believes itself justified in the statement that the site is commodious, accessible, and adapted by nature to the special ends it is intended to serve, in a degree beyond any belonging to any other city.

On Norember 22 the Commission submitted to the President, with a copy of the map of the park showing the tracts condemned for public uses, a schedule of what it considered to be just compensation in each case, and this compensation the President approved on November 26. The Commission is now proceeding to settle as rapidly as it can with the owners whose lands are to be acquired by mutual agreement.

In the following schedule the land to be acquired by agreement is shown distinct from that where the owners have refused the Commis.

(* Congressional Record, March 1, 1889, p. 2663.) Mr. DibBLE. * * * In the first place, Mr. Speaker, the project as set forth in the bill is for the purchase of not less than 100 acres of land, as members will see from the design and plan in front of the Reporter's desk. I am speaking to the Zoological Park bill, a bill reported by the Committee onPublic Buildings and Grounds, in accordance with the design and plan now in front of the Reporter's desk. 
sion's prices and where the land remains to be acquired by the process of condemnation specified in the act:

Land acquired by agreement with the owners.

\begin{tabular}{|c|c|c|}
\hline Owner. & Acres. & $\begin{array}{c}\text { Price agreed } \\
\text { upon. }\end{array}$ \\
\hline 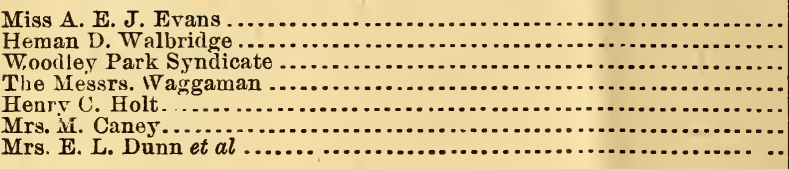 & $\begin{array}{r}94.050 \\
14.4 .50 \\
5.103 \\
2.350 \\
13.360 \\
1.440 \\
.392\end{array}$ & $\begin{array}{r}\$ 94,860.00 \\
14,450.00 \\
1.00 \\
5,875.00 \\
40,000.00 \\
3,000.00 \\
170.76\end{array}$ \\
\hline Total & 131.145 & $158,356.76$ \\
\hline
\end{tabular}

List of property which must be acquired by condemnation.

\begin{tabular}{|c|c|c|}
\hline Owner. & Acres. & $\begin{array}{l}\text { Valuation of- } \\
\text { fered by Com- } \\
\text { mission and } \\
\text { approved by } \\
\text { President. }\end{array}$ \\
\hline 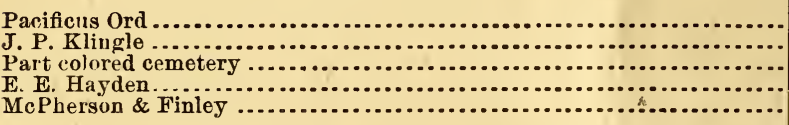 & $\begin{array}{r}24.570 \\
6.180 \\
1.700 \\
.670 \\
.315\end{array}$ & $\begin{array}{r}\$ 9,828.00 \\
4,994.00 \\
3,000.00 \\
800.00 \\
200.00\end{array}$ \\
\hline 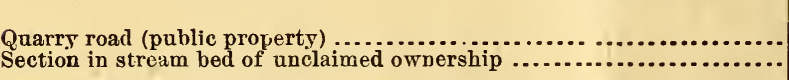 & $\begin{array}{r}33.435 \\
.846 \\
1.060\end{array}$ & $\begin{array}{r}18,772.00 \\
\hdashline . .6 \\
\hdashline\end{array}$ \\
\hline Total ....................................... & 1.906 & (n............... \\
\hline Grand total................ & 166.486 & $\overline{177,} \overline{128.76}$ \\
\hline
\end{tabular}

The Commission calls attention to the fact that the accuracy of the estimates of the probable cost of this land, submitted by the Smithsonian Institution to the Appropriation Committees of both houses of Congress, and repeatedly referred to in debate, has been verified by the cost of the purchases made up to date. Of the site of 121 acres that was originally marked out on the maps and models submitted to Con. gress, 90 acres have now been purchased by agreement. The estimate to Congress of the cost of these 90 acres, taken separately, was $\$ 109,750$, whereas the actual cost of this ground, by agreement, is $\$ 104,316$. The plans herewith submitted show-

(1) The relative area and location of the park, on a general map of the city and suburbs.

(2) The actual metes and bounds with the names of the original own. ers, on a copy of the map described in the act.

Judging from the progress thus far, it now seems probable that the land remaining to be acquired by condemnation and appraisement proceedings, will cost the Government a sum not widely differing from the Commission's valuation; and if this should prove to be the case, after allowing for incidental expenses, the total cost of the entire site will fall so far within the $\$ 200,000$ appropriated, even after the purchase of about 45 acres beyond the originally contemplated area, as to leave a balance, which may be applied to necessary preliminary expenses.

Before the expiration of the present fiscal year the Zoological Park Commission will bare completed the duties with which it was charged 
by the act of Congress-which called it into existence, and the title to the lands it has purchased will be vested in the United States. Pending the completion of the condemnation proceedings now in progress, and the submission of a final report, it is extremely desirable that Congress should enact further legislation in regard to the park. The Commission has no authority to put up fences aud lay out roads or grounds, or to erect buildings, nor is it even certain that it has the right to accept donations. The park is leclared by Congress to be "for the ad. vancement of science and the instruction and recreation of the people." In the construction of ponds and lakes, and the erection of iuclosures and buildings for the purposes of zoological science, a stage will soon be reached where scientific direction seems obviously desirable; and it is respectfully represented to Congress that any means for laying out and improving the grounds can be most advantageously used in view of the purpose of Congress as to the ultimate disposition of the park now wheu the foundations of its future usefulness are being laid.* If the very considerable collection of living animals now in the custody of the Smithsonian Institution is to form the nueleus of the zoological park collection its transfer should be effected by legislative enactment and suitable measures taken for its maintenance. The Commission is of the opinion that the collection referred to should, with the consent of the regents of the Institution, be transferred to the zoological park as soon as possible after the Government takes full possession of the site.

JoHN W. NoBLE, Secretary of the Interior, J. W. Douglass, Prest. Board Com. Dis. Col., S. P. LANGLET, Secretary Smithsonvan Institution, Commissioners for the establishment of a Zoological Park in the District of Columbia.

\section{Exhibit A.}

Office of the Commissioners of the Zoological Park, Smithsonian Institution, Washington, D. C., April 15, 1889.

SIR: In accordance with an act of Congress approved March 2, 1889 (Public No. 113), for the establishment of a zoological park in the District of Columbia, the Commissioners created by this act, and charged with the duty of its fulfillment, give notice that they have been " authorized and cirected to make an inspection of the country along Rock Creek, between Massachusetts avenue extended and where said creek is crossed by the road leading west from Brightwood (commonly known as the Military road), and to select from that district of country such a tract of land, of not less than 100 acres, which shall include a section of the creek, as said Commission shall deem to be suitable and appropriate for a zoological park."

They further give notice that the act declares:

"That the said Commission shall cause to be made a careful map of said zoological park, showing the location, quantity and character of each parcel of private property to be taken for such purpose, with the names of the respective owners inscribed

\footnotetext{
* (Congressional Record, March 1, 1889, p. 2662.) Mr. Breckinridge. I append the report of the Committee on Public Grounds that the record may show the exact object in view. There is absolute protection from jobbery in the fac that this is to be under the supervision of the Smithsonian Institution.

(P. 2663.) Mr. DibBle. We are proud of the Smithsonian, and the Smithsonian has already, by gift, not by purchase, the nucleus of a collection, * * * and I am informed by the Secretary of the Smithsonian that this place furnishes the right kind of location * * * for the propagation and perpetuation of these rapidly disappearing species of American animals, while at the same time it will serve the $r$ arposes of a public park.
} 
thereon, and the said map shall be filed and recorded in the publlc records of the District of Columbia ; and from and after that date the several tracts and parcels of land embraced in such zoological park shall be held as condemned for public uses, subject to the payment of just compensation, to be determined by the said Commission, and approved by the President of the United States, provided that such compensation be accepted by the owner or owners of the several parcels of land."

"That if the said Commission shall be unable to purchase any portion of the land so selected and condemned within thirty days after such condemnation, by agreement with the respective owners, at the price approved by the President of the United States, it shall, at the expiration of such period of thirty days, make application to the supreme court of the District of Columbia, by petition, at a general or special term, for an assessment of the value of such land, and said petition shall contain a particular description of the property selected and condemned, with the name of the owner or owners thereof, and his, her, or their residences, as far as the same may be ascertained, together with a copy of the recorded map of the park; and the said court is hereby authorized and required, upon such application, without delay, to notify the owners and o ccupants of the land and to ascertain and assess the value of the land so selected and condemned by appointing three commissioners to appraise the value or values thereof, and to return the appraisement to the court; and when the values of such land are thus ascertained, and the President shall deem the same reasonable, said values shall be paid to the owner or owners, and the United States shall be deemed to have a valid title to said lands."

In view of the desirability, in selecting said site, of taking into account the value of the various parcels of land which the Commission has the power to include, the Commissioners hereby invite you, as an owner of property in the region indicated, to furnish them not later than May 1, 1889, with a written statement of the lowest price at which you will agree to sell, for the purpose named above, the following-described real estate, which they understand is owned by you, viz:

There is open for inspection in this office, between the hours of 2 and 4 p. m., a map showing the Rock Creek region, on which are laid down the names of real estate holders, and the bounds and contents of th ir properties, so far as these are known to the Commissioners.

\author{
JoHN W. NOBLE, \\ Secretary of the Interior, \\ William B. WebB, \\ Pres. Board Com. Dis. Col., \\ S. P. LANGLeY, \\ Secretary, Smithsonian Institution, \\ Commissioners
}




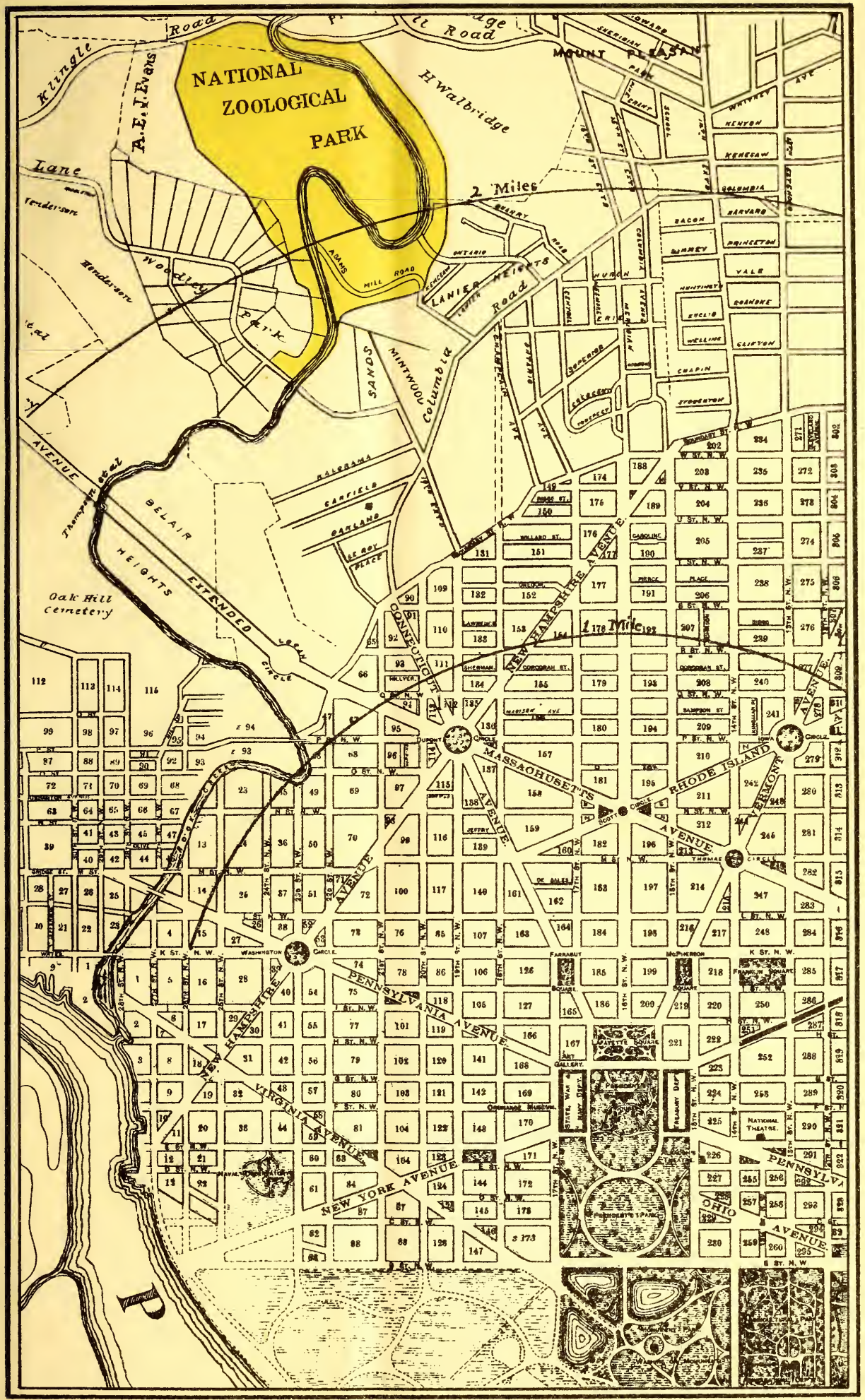

MaP SHOWING THE LOCATION OF THE NATIONAL ZOQLOGICAL PARK. 





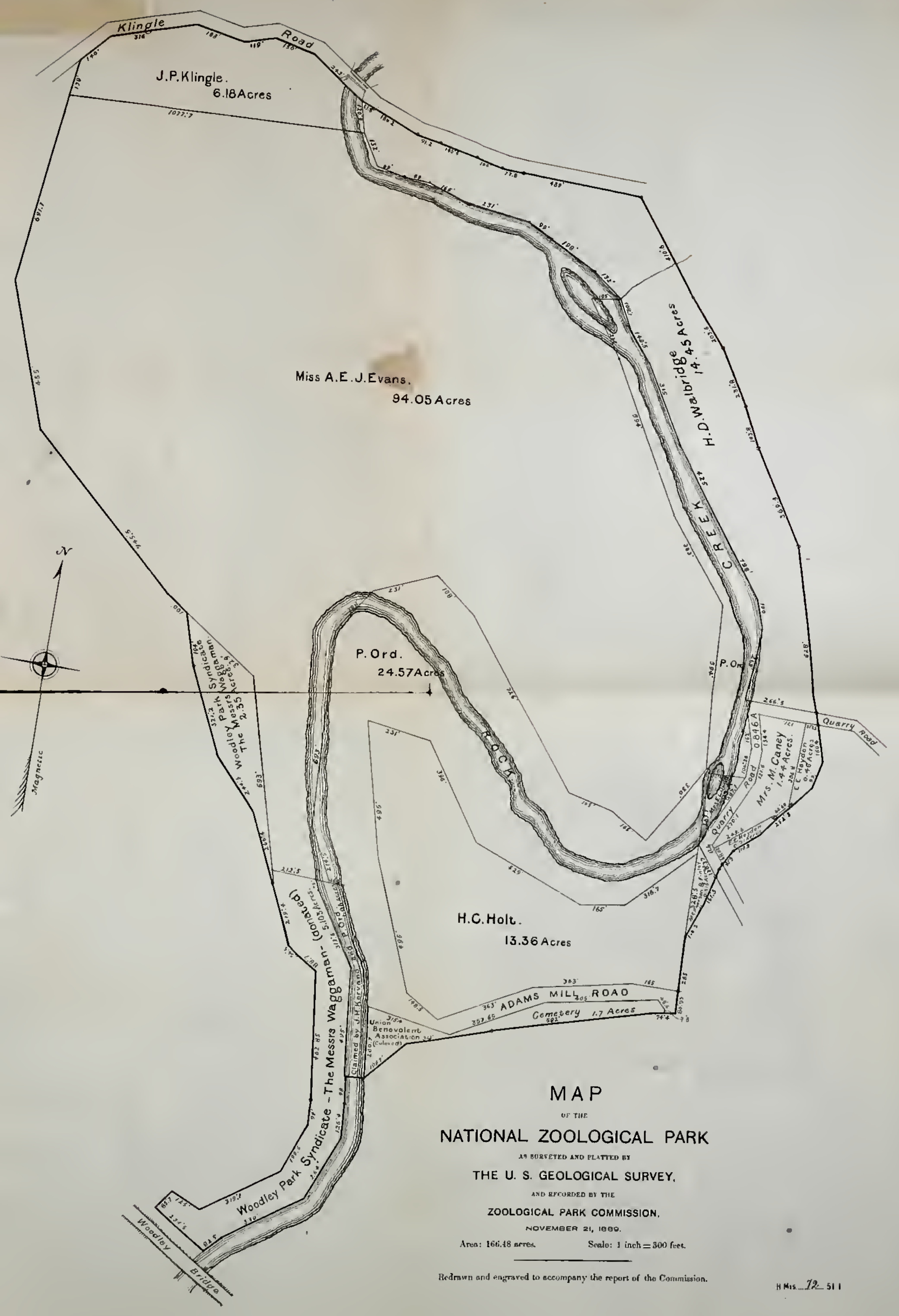


SMITHSONIAN INSTITUTION LIBRARIES 